\title{
Ajánlások földikutya-állományok egyedszámváltozásának egységes nyomon követeséhez
}

\author{
Moldován Orsolya ${ }^{1,2}$, Schneider Viktor ${ }^{3}$, Szél László $^{1}$ és \\ Németh Attila ${ }^{2,4^{*}}$ \\ ${ }^{1}$ Hortobágyi Nemzeti Park Igazgatóság, 4024 Debrecen, Sumen u. 2. \\ ${ }^{2}$ Debreceni Egyetem, Természetvédelmi Állattani és Vadgazdálkodási Tanszék, \\ 4032 Debrecen, Böszörményi út 138. \\ ${ }^{3}$ Kiskunsági Nemzeti Park Igazgatóság, 6000 Kecskemét, Liszt Ferenc u. 19. \\ ${ }^{4}$ Magyar Madártani és Természetvédelmi Egyesület, 1121 Budapest, Költő u. 21. \\ *E-mail: dr.attila.nemeth@gmail.com
}

\begin{abstract}
Összefoglaló: A földikutyák Magyarország legveszélyeztetettebb emlősállatai közé tartoznak. Kizárólagosan talajlakó életmódjuk miatt állományaik egyedszámának meghatározása, állományváltozásaik nyomon követése roppant nehéz feladat, pedig nagy szükség lenne megbízható állományadatokra. Az 1980-as évek óta számos kezdeményezés történt monitorozásuk módszertanának kidolgozására. Publikációnkban áttekintjük a hazai természetvédelmi gyakorlatban a földikutyaállományok egyedszámának nyomon követesére alkalmazott módszereket. Az utóbbi években öszszegyült gyakorlati tapasztalatok alapján megvitatjuk az olyan, állományfelmérések során felmerülő nehézségeket, mint a földikutya-túrások azonosítása, az élőhelyek talajtani sokfélesége által okozott módszertani problémák, vagy az állományfelmérés időpontjának megválasztási nehézségei. Javaslatokat fogalmazunk meg egy egységes, a Kárpát-medence-szerte bárhol alkalmazható földikutyamonitorozási protokoll kidolgozásához.
\end{abstract}

Kulcsszavak: Nannospalax (superspecies leucodon), állományfelmérés, monitorozás, egyedszámbecslés, módszertan, élőhelyi jellemzők

\section{Bevezetés}

A természeti értékek állapotának, illetve állapotváltozásának nyomon követése, vagyis monitorozása a természetvédelem meghatározó feladata (Yoccoz et al. 2001), amely ritka vagy veszélyeztetett élölények esetében különösen nagy jelentőséggel bír (Schemske et al. 1994). Az egyedszám és elterjedés időbeli változásainak, ingadozásainak ismerete a természetvédelmi szempontból jelentős fajok esetében elengedhetetlen fontosságú a gyakorlati természetvédelmi feladatok és prioritások pontos és helyes meghatározásához (Yoccoz et al. 2001). 
Bizonyos élőlények esetében, például azok rejtett életmódja miatt, a monitorozási tevékenység komoly kihívást jelent (Mills et al. 2000). A hazai természeti értékek sorában ilyenek a nyugati földikutya (Nannospalax [superspecies leucodon] Nordmann, 1840) kisfajok Magyarországon előforduló állományai. A földikutyák kizárólagosan talajlakó életmódja miatt elterjedésük és egyes állományaik egyedszámának meghatározása, illetve a populációk állományváltozásainak nyomon követése roppant nehéz feladat. Ugyanakkor a fajcsoport kritikus természetvédelmi helyzete miatt nagy szükség lenne megbízható állomány- (és elterjedési) adatokra. Mindezt jól mutatja, hogy a hazai földikutyák monitorozására vonatkozó legelső próbálkozások már az 1980-as években megkezdődtek (Palotás 1982, 1987, Végh 1986). Az egységes módszertan szerinti monitorozására irányuló törekvések az ezredfordulótól új lendületet vettek (Horváth 1999, Horváth és Vadnay 2001). Valamennyi hazánkban alkalmazott módszer a földikutyák jelenlétének a felszínről is észlelhető nyomaira összpontosított, a túrások számát és pozícióját követte nyomon. Mindez összhangban állt a földikutyák monitorozásának külföldön alkalmazott módszereivel (Mikes et al. 1982, Zuri és Terkel 1996). Az ezredfordulón kidolgozott módszer (Horváth és Vadnay 2001) sokáig az egyetlen volt a hazai földikutya-állományok felmérésére (Bihari et al. 2009). Azonban az ismert földikutya-populációk számának növekedésével (Németh et al. 2020) egyre több élőhelyen vált szükségszerüvé az állományok rendszeres nyomon követése. Ezt a tevékenységet ugyanakkor a különböző felmérők nem egységes és nem koordinált módon végezték. Az érintett nemzeti park igazgatóságok müködési területein olyan monitorozási eljárások jelentek meg a gyakorlatban, melyek módszertanilag a korábbi hazai gyakorlatra (Horváth 1999, Horváth és Vadnay 2001) épültek ugyan, ám részleteiben attól mégis eltértek. A különböző földikutya-élőhelyeken párhuzamosan alkalmazott felmérési módszerek idővel egymástól is egyre jobban különböztek. Ez a helyzet ma is megfigyelhető: a Kiskunsági, a Körös-Maros, vagy éppen a Hortobágyi Nemzeti Park Igazgatóság múködési területein eltérő módszereket alkalmaznak a földikutya-állományok évenkénti felmérése során. Így azonban az ország egyes földikutya-élőhelyeiről rendelkezésre álló állomány-, vagy állományváltozás-adatok nem, vagy csak részben hasonlíthatók össze egymással. A természetvédelmi stratégiák megtervezése, a prioritások és szükséges intézkedések meghatározása során mindez számos nehézséget okoz. A hazánkban élő földikutyakisfajok állományai jellemzően több nemzeti park igazgatóság müködési területe között oszlanak meg, az eltérő felmérési módszerek miatt azonban az egyes kisfajokra vonatkozó állományadatok nem összevethetők és nem összeadhatók. Amennyiben mégis összegezzük őket, akkor az egyes kisfajok országos állományadatai, állományváltozásuk trendjei, valamint a rájuk alapozott stratégiák és akciótervek megbízhatósága válik kérdésessé. 
Jelen publikációban áttekintjük a hazai természetvédelmi gyakorlatban a földikutya-állományok egyedszámának nyomon követesére alkalmazott módszereket. Az utóbbi években összegyült gyakorlati tapasztalatok alapján megvitatjuk az állományfelmérések során felmerülő nehézségeket, és javaslatokat fogalmazunk meg egy egységes, a Kárpát-medencében bárhol alkalmazható földikutya-monitorozási protokoll kidolgozásához.

\section{Anyag és módszer}

A földikutya-monitorozással kapcsolatos problémák megvitatásának szakmai alapját azok a terepi adatok adják, melyek a földikutya-áttelepítések 2013-as kezdete óta (Ruzsa et al. 2020) gyültek össze az állatok befogása, illetve az áttelepített egyedek utánkövetése során. Az áttelepítésekhez kapcsolódó terepi tevékenységek közben számos gyakorlati kérdés és probléma is felmerült. Ezek a helyzetek lehetővé tették a 2000-es évek közepétől mind nagyobb számban rendelkezésre álló monitorozási adatok megbízhatóságának egyfajta ellenőrzését, objektív értékelését.

Az említett gyakorlati problémák, élethelyzetek az alábbiak voltak:

i) Az áttelepítés érdekében végzett befogások során valóban annyi földikutyaegyedet lehetett-e megtalálni egy élőhelyen, mint amit a monitorozási adatok mutattak, és az egyedek valóban az előre jelzett helyeken voltak-e? Ennek ellenőrzésére a hajdúhadházi Liget-legelőn, a debreceni (nyulasi) lucernaföldön és a debrecen-józsai építési telkeken, a Bajai Földikutya Rezervátumban, valamint a Kelebia és Ásotthalom közötti földikutya-élőhelyeken nyílt lehetőség.

ii) Bizonyos esetekben, a befogásokat követően sor került az áttelepített egyedek eredeti járatrendszerének teljes feltárására. Ezek dokumentációja fontos információkkal szolgál arra vonatkozóan, hogy a járatrendszerek ténylegesen akkorák-e, mint a monitorozási felmérések alapján egy egyed territóriumaként definiált terület, valamint, hogy az egy egyednek tulajdonított túrások valóban egyazon járatrendszerhez kapcsolódtak-e. Járatrendszerek teljes kiásására a hajdúhadházi, a debrecen-józsai és a bajai populációk élőhelyein került sor.

iii) Az áttelepített egyedek sorsát az elengedését követően a legtöbb akció esetében egy éven át, heti rendszerességgel nyomon követték (Ruzsa et al. 2020). Mivel az új élőhelyeken más földikutyák nem éltek, csupán a betelepített egyedek - amelyek tulajdonságai (koruk, nemük, elengedési helyük) pontosan ismertek voltak -, így mindaddig példátlan körülmények között nyílt lehetőség a földikutyák tanulmányozására. A gyüjtött adatok számos kérdésre segítenek választ adni: Miként építi ki a földikutyaegyed a teljes járatrendszerét az új élőhelyen? Milyen 
az egyes földikutyák térbeli és időbeli aktivitása az év során? Mennyi túrás tartozik egyazon példányhoz? Milyen az egyes egyedek territóriumának mérete és alakja? Különböző körülmények között milyen méretü és alakú túrásokat készítenek a földikutyák? Áttelepített földikutyák tevékenységének nyomon követése Bagamér közelében (Kék-Kálló mente) (Moldován 2014), Pocsaj mellett (Löszletörés), Baján (Schneider et al. 2019), valamint a Madarasi gyepen történt.

Mindezek mellett 2018 és 2019 során több alkalommal került sor olyan állományfelmérésekre és terepi bejárásokra, melyeken több nemzeti park igazgatóság munkatársai együtt vettek részt. Ezeknek célja az egyes élőhelyeken felmerülő, állományfelméréshez kapcsolódó nehézségek megvitatása, a tapasztalatok megosztása, együtt gondolkodás és a használt módszerek közösen történő fejlesztése volt. A Hortobágyi, a Körös-Maros, és a Duna-Ipoly Nemzeti Park Igazgatóságok munkatársainak részvételével zajló események közös tapasztalatai, valamint a különböző élőhelyeken évek alatt összegyült tudás megfelelő bázist biztosítanak a felmérési módszerek értékeléséhez, a monitorozás közben jelentkező problémák megválaszolásához, és egy, a térségben bármelyik élőhelyen jól használható földikutya-állományfelmérő módszertan kidolgozásához.

\section{Eredmények és megvitatásuk}

\section{Földikutya-állományok felmérésre alkalmazott hazai és külföldi módszerek áttekintése}

Hazánkban elöször valószínűleg Palotás végzett állománybecslést a hajdúbagosi földikutya-populáció élőhelyén 1982-ben, majd 1987-ben (Palotás 1982, 1987). Eredményei azonban csupán kéziratos kutatási jelentés formájában láttak napvilágot. Végh (1986) ugyanakkor alaposan dokumentált állományfelmérést végzett szintén Hajdúbagoson. Bár lehetőségeihez mérten az összes észlelhető túrást rögzítette, az egyedszám meghatározásához csak a „nagy túrásokat” használta. Vásárhelyi (1926) nyomán feltételezte ugyanis, hogy minden egyed csupán egyetlen nagyméretủ túrást épít az év során, mivel az alatt párzó- vagy utódnevelö, esetleg telelőkamra található.

Az ezredfordulón Horváth és Vadnay (2001) más módszert használtak a földikutya-állományok egyedszámának meghatározására. Az élőhelyek részletes bejárása során a friss túrások számolása alapján végeztek egyedszámbecslést. Földikutya-előfordulásnak a kerek keresztmetszetü, $6 \mathrm{~cm}$-nél nagyobb átmérőjü „hurkákból” álló kupacok jelenlétét tekintették (Vadnay 2000, Horváth és Vadnay 2001, 2006). 
Gyakorlatilag ezzel párhuzamosan született meg a Nemzeti Biodiverzitásmonitorozó Rendszer földikutya-állományok monitorozására javasolt, nagyon hasonló módszertanú protokollja (Horváth 1999). A készítése idején jellemző hiányos ismeretek ellenére a szakirodalomra alapozva megalkotott, részletesen kidolgozott módszertant a gyakorlatban soha, sehol nem alkalmazták. A protokoll a mintavételt két periódusban javasolja, a téli időszakban (december-február) 1-3 terepbejárással, és kora tavasszal (március-április) 8-11 bejárással. A bejárások során a telelőkamrák és a túráshalmazok középpontjának (GPS) koordinátáit szükséges feljegyezni (Horváth 1999).

A 2000-es évek végén Bihari és munkatársai (2009) a Horváth és Vadnay (2001) által kidolgozott módszert fejlesztették tovább. A novemberben zajló monitorozás során sávos felmérést alkalmaztak, a teljes területet bejárva egymástól 200 méterre levő párhuzamos útvonalak mentén. Földikutyatúrásnak a $60 \mathrm{~cm}$-nél nagyobb alapátméröjü, a 4 cm-t meghaladó átméröjü hurkákat tartalmazó kupacokat tekintették. Csak a friss túrások rögzítésére került sor, és tekintettel a földikutyák erősen territoriális viselkedésére (Vásárhelyi 1926) a 4-10 túrásból álló „túrásbokrokat" tekintették egy egyedtől származó életnyomnak (Bihari et al. 2009).

Az elmúlt évtized során a különböző nemzeti park igazgatóságok területén nem egységes módszertan szerint zajlott a földikutya-állományok monitorozása. A Hortobágyi Nemzeti Park Igazgatóság földikutya-állományait évente egyszer vagy többször, de csak tavasszal mérik fel. A földikutyatúrások azonosítása érdekében, ha szükséges, a járatrendszereket is megnyitják. A már felmért túrásokat széttapossák, a későbbi ismételt rögzítés elkerülése érdekében. A monitorozás során a földikutyaegyedek feltételezett pozíciója - vagyis a földikutyatúrások egymástól vizuálisan elkülönülő csoportjainak középpontja - mellett valamennyi, a területen megtalálható földikutyatúrás helyzete is rögzítésre kerül. A Kiskunsági Nemzeti Park Igazgatóság földikutya-állományai esetében évente egyszer, őszszel történik állományfelmérés, melynek során sávos felmérést alkalmaznak. A monitorozás során a földikutyaegyedek feltételezett pozíciója (a földikutyatúrások egymástól vizuálisan elkülönülő csoportjainak középpontja) kerül rögzítésre néhány háttéradattal együtt (pl. az egyedhez tartozó túrások száma, mérete, kora) (Németh et al. 2015). A Körös-Maros Nemzeti Park területén a tapasztalt aktivitásnövekedések idején, az év során többször, de előre nem definiált időszakokban mérik fel a földikutya-állományokat. A bejárások során a területen található összes földikutyatúrás helyzete rögzítésre kerül. Az utóbbi években számos alternatív lehetőség is felmerült a földikutya-populációk monitorozására a drónos vagy klasszikus légifelvételektől a talajradar alkalmazásáig (Boldogh 2011, Páll és Sipos 2017). 
A hazánkban alkalmazott módszerek nagymértékben hasonlítanak azokra, amelyeket más országokban dolgoztak ki földikutya-állományok felmérésére, illetve az egyedek tevékenységének kutatási célból történő nyomon követésére. Az egykori Jugoszlávia területén, a vajdasági Deliblát homokpusztáin előre kijelölt egyhektáros kvadrátokban április és május hónapokban mérték fel a földikutyák territóriumait a friss túrások rögzítésével (Mikes et al. 1982). A Szabadkaihomokpusztákon ugyanezen módszer továbbfejlesztett változatát alkalmazva először elsimították a meglévő túrásokat, majd folyamatosan nyomon követték az új túrások megjelenését, így becsülve meg a populáció egyedszámát (Delić 2007).

Izraelben szintén a földikutyák viselkedésének vizsgálata érdekében mérték fel az egyedek territóriumát, illetve követték az állatok járatépítését. Zuri és Terkel (1997) ugyanazon a mintaterületen több egymást követő felmérést alkalmazva, az új túrások folyamatos nyomon követésével és jelölésével pontosan felmérték a járatrendszereket, aminek révén képesek voltak elkülöníteni az egyes földikutyaegyedek territóriumát. Egy másik tanulmányukban, ahol jeladóval ellátott földikutyák tevékenységét követték nyomon, ugyanezek a szerzők rámutatnak, hogy a túrások csupán egyszeri felmérése alapján azonban rendkívül problémás pontosan feltérképezni az egyedek territóriumát, s elkülöníteni egymástól az egyes egyedek járatrendszerét (Zuri és Terkel 1996).

Érdekes, új megközelítéssel találkozhatunk Zidarova és Kostova (2021) tanulmányában, ahol a földikutya jelenlétének nagy léptékủ monitorozása érdekében transzektes módszert mutatnak be. A módszer nem alkalmas az egyes állományok állományváltozásának nyomon követésére, hanem táji, régiós léptékben képes követni a földikutyák elterjedésének, jelenlétének változásait.

\section{A földikutya-monitorozás problémái}

Az elmúlt évek állományfelmérései, állománybecslései, valamint az áttelepítéssel létrehozott populációk monitorozása során számos problémás kérdés merült fel, amik a felmérés eredményét, megbízhatóságát nagyban befolyásolják. Az alábbiakban megtárgyaljuk ezeket a pontokat, bemutatva a rendelkezésre álló releváns adatokat, amik segíthetnek a kezelésükben.

\section{Földikutya jelenlétének azonositása}

A földikutya előfordulásáról egy területen a túrások árulkodnak, amelyek az egyedüli, a felszínen is könnyen észlelhető nyomai az állat jelenlétének (Vidacs et al. 2013). Azonban más, talajlakó vagy akár részben a felszínen élő állatok, mint a közönséges vakond (Talpa europaea Linnaeus, 1758) vagy a közönséges kószapocok (Arvicola amphibius Linnaeus, 1758) is hasonló túrásokat hozhatnak létre (Vásárhelyi 1930). Elméletileg lehetséges az egyes fajok elkülönítése túrás- 
morfológiai alapokon. A földikutyák túrásaira jellemző, hogy általában (i) nagyméretüek (60 cm-t meghaladó átmérővel), (ii) a szomszédos túrások egymástól mérhető távolsága nagy (1,5-2 m), (iii) a túrások térbeli elrendeződése szabályos, közel egyenes vonal mentén sorakoznak, (iv) a túrások tetején megfigyelhető ún. földhurkák átméröje nagy $(6-9 \mathrm{~cm})$, (v) továbbá a földikutyatúrásokban a talajjal keveredve megfigyelhetőek rövid gyökérdarabok, melyek vége hegyes szögben van leharapva (Boldog 2010, Németh 2011) (1. ábra). Ugyanakkor Boldog (2010, 2011) felhívja rá a figyelmet, hogy a túrások morfológiai jellemzőit leginkább az élőhely talajának tulajdonságai határozzák meg (2. ábra). Egy homoktalajú élőhelyen teljesen másként néznek ki a földikutyatúrások, mint morzsalékos csernozjom talajon (Boldog 2010). Nem csupán a homoktalaj és a „feketeföld” esetében adódhatnak jelentős különbségek a túrások alakját, méretét vagy szerkezetét tekintve, hanem például a talaj agyagtartalma is fontos tényező lehet. Battonya, Debrecen-Józsa, Albertirsa vagy Mezőtúr földikutya-élőhelyeinek túrásai között is jelentős (morfológiai és méretbeli) különbségek adódnak. A legszélsőségesebb példa Mezőtúr, ahol a 2019. évi állománytérképezések során (Németh et al. 2020) a felszín alatti járatok vizsgálata után olyan túrások esetében bizonyosodott be, hogy földikutyához tartoznak, melyeket más élőhelyek esetében joggal vélnénk vakondtúrásnak. A talajlakó állatok járatainak jellemzői tehát bizonyos esetekben megbízhatóbb határozóbélyegek lehetnek, mint a túrások sajátosságai, így - bár a járatok vizsgálata a túrások szemlevételezésénél problémásabb feladat - mégis érdemes lehet ezeket is vizsgálni. A földikutyák járataira jellemző, hogy (i) rendszerint nehéz megtalálni őket a túrás alatt, (ii) a járat legtöbbször nem a túrás közepe alatt található, hanem a szélénél, érintő mentén halad, (iii) a járatok kerekek, nagyméretüek $(>6 \mathrm{~cm})$, tapinthatóan kemény falúak, és nem lógnak be gyökerek a járatba, (iv) a járatok egyenes lefutásúak, nem kanyargóak, valamint (v) megfelelő talajtani jellemzők (kötött, agyagos talajok) esetén a járatok falában láthatóak a földikutya orrának jellegzetes, mással össze nem téveszthetö lenyomatai (Németh 2011) (1. ábra). A felsorolt bélyegek megléte igazolni tudja, hogy a járatrendszer földikutyához tartozik.

\section{Talajtani jellemzök szerepe}

Az élőhely talajtani jellemzői nem csupán a túrások megjelenésére, de a földikutyák egész életére jelentős hatást gyakorolnak (Li et al. 2015, Lövy et al. 2015, Šklíba et al. 2016). Ezen hatások következtében a földikutyák viselkedése, és így járatrendszerük jellemzői is nagyban különbözhetnek az egyes élőhelyek között a talajtani jellemzők függvényében (Lövy et al. 2015, Šklíba, et al. 2016). A talajtani jellemzők egyaránt befolyásolják a földikutyák territóriumméretét, egyedsürüségét, a földikutya-aktivitás mértékét és az aktivitási időszakok időbeli eloszlását 

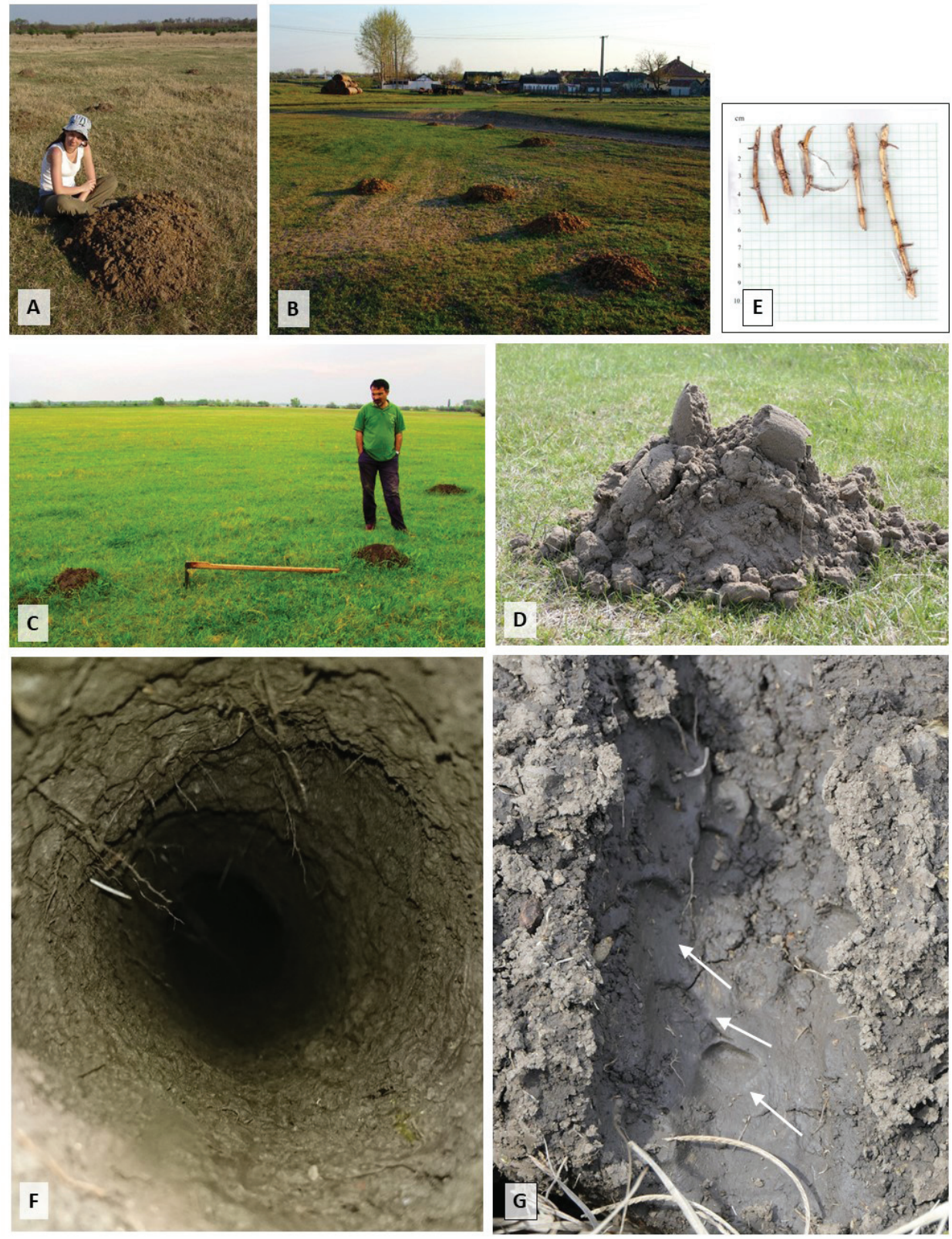

1. ábra. A földikutyatúrások és -járatok jellemzői. A: a túrások rendszerint nagyméretủek, B: a túrások térbeli elrendeződése szabályos, közel egyenes vonal mentén sorakoznak, C: a szomszédos túrások egymástól mérhető távolsága nagy, D: a túrások tetején megfigyelhető ún. földhurkák mérete nagy, E: a földikutyatúrásokban a talajjal keveredve megtalálhatók rövid gyökérdarabok, melyek vége hegyes szögben van leharapva, F: a járatok nagyok, kerek alakúak és tapinthatóan kemény falúak, G: a járatok falában láthatóak a földikutya orrának jellegzetes lenyomatai. 

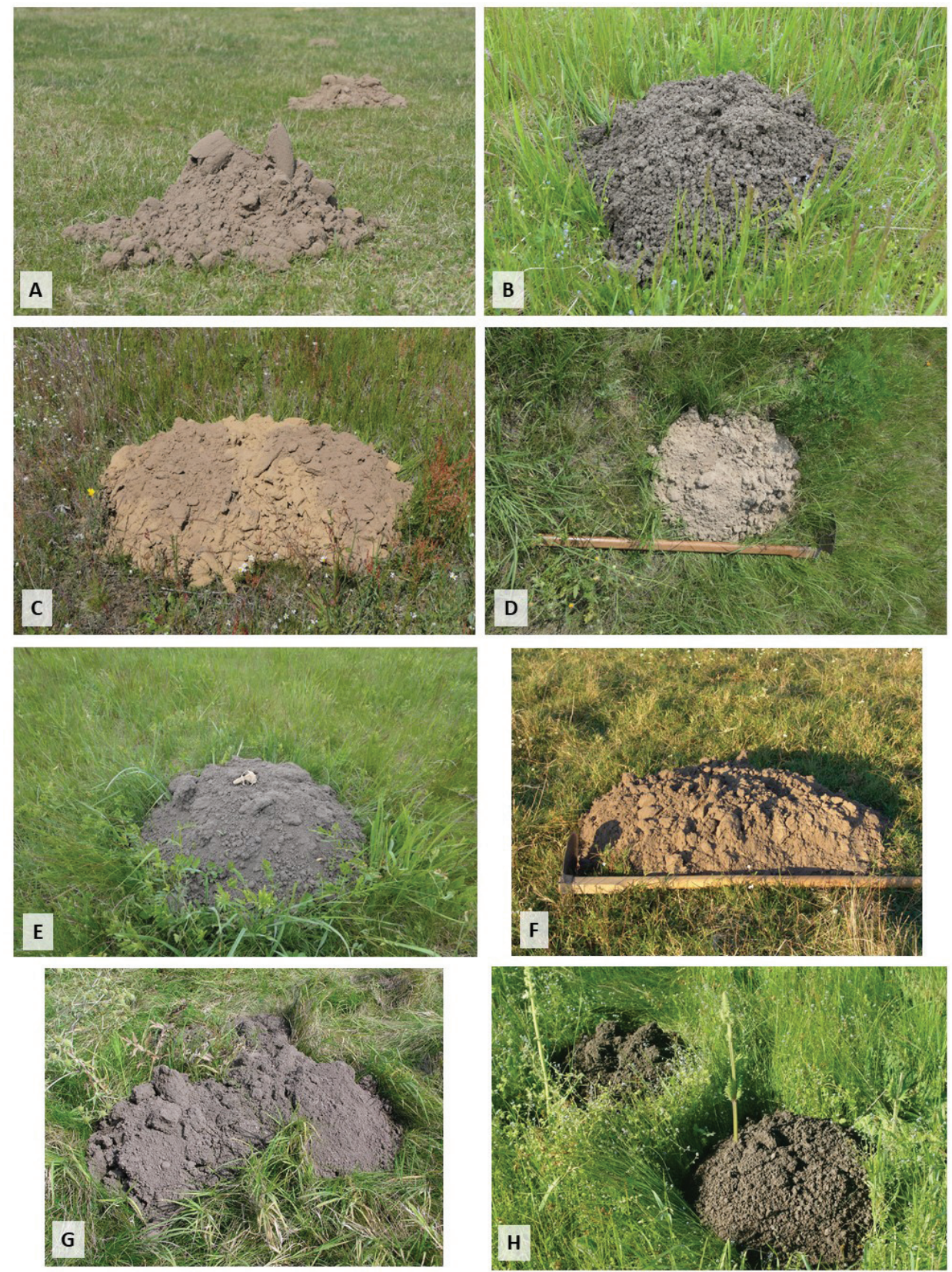

2. ábra. Földikutyatúrások alaktani és méretbeli sokfélesége. (A különböző képeken látható túrások egymással nem méretarányosak.) A: Hajdúhadház, Liget-legelő, B: Mezőtúr, téglagyár, C: Bagamér, Hajdúsági Tájvédelmi Körzet, D: Albertirsa, belterület, E: Albertirsa, Gerje-mente, F: Hajdúbagosi Földikutya Rezervátum, G: Debrecen-Józsa, Tócó-mente, H: Tompapusztai-gyep. 
vagy hosszát, a járatrendszerek alakját, valamint a túrások elrendeződését és egymástól való távolságát. Mindezek ismerete nélkül nem lehet helyesen értelmezni a terepen felvett adatokat.

A kötött talajú és a homoktalajú élöhelyek között a földikutyák szempontjából hazánkban is jelentős különbségek figyelhetők meg. A kötött talajú élőhelyeken jellemző magasabb produktivitás, valamint a táplálékfoltok egymáshoz való közelsége kisebb kiterjedésü járatrendszereket, és így nagyobb egyedsürüséget eredményez. A járatrendszerek nemcsak kisebb kiterjedésúek, de sürübben is ágaznak el. Ugyanakkor az ásásnak és a járatépítésnek magasabb energiaigénye van a kötött talajú élőhelyeken, így a földikutyák felszínről megfigyelhető aktivitása ezeken a helyszíneken sokkal kisebb. Az egy járatrendszerhez, vagyis egy egyedhez tartozó (friss) túrások száma jellemzően sokkal alacsonyabb. A túrások mérete és a szomszédos túrások távolsága is jellemzően kisebb a kötött talajú földikutyaélőhelyeken. Mindez pedig azt is okozza, hogy a földikutyatúrások elkülönítése más talajlakó életmódot folytató kisemlősök túrásaitól kifejezetten problémás lehet ilyen területeken.

\section{A földikutyák territóriumának mérete}

A földikutyaegyedek territóriumának méretét sok tényező befolyásolja. Az élőhely talaja (Lövy et al. 2015) és az élőhelyen belül a lakhelyét jelentő folt táplálékkínálata mellett jelentős befolyásoló tényezők az egyed kora, ivara, testmérete és fizikai adottságai is. Fontos, hogy a monitorozást végző személynek - a felmérendő élőhely talajtani és növényzeti jellemzői alapján - legyen információja arról, hogy mekkora a földikutyák várható átlagos territóriummérete, máskülönben szélsőségesen alul- vagy túlbecsülheti az állomány méretét. A debreceni földikutya-populáció esetében a megtalálást követően pontosan ez történt. Az állomány egy lucernaföldön él, ahol a táplálékbőség messze felülmúlja a természetes élőhelyeket, ami korábban nem tapasztalt egyedsürüségben képes az állományt fenntartani. Emiatt az első felmérés alkalmával a valós egyedszámnak csupán az ötödét valószínüsítették (Németh et al. 2020). Egy új földikutya-populáció létrehozása érdekében végzett természetvédelmi akció keretében, a befogások során vált világossá a debreceni populáció valós egyedszáma (Ruzsa et al. 2020). A terepen rögzített túrásmintázatok helyes feldolgozásához, értékeléséhez tehát elengedhetetlen, hogy legyenek a várható egyedsürüséget befolyásoló faktorokra vonatkozó információink.

A legtöbb, a járatrendszer kiterjedésére vonatkozó adat homoktalajú élőhelyek esetében áll rendelkezésre. A hajdúhadházi Liget-legelőn 2013-ban, illetve a Bajai Földikutya Rezervátumban 2020-ban kiásott teljes járatrendszerek azt mutatták, hogy mindkét élőhelyen a földikutyaegyedek egész csatornahálózata egy 30 méter 
átmérőjü körön belül volt megtalálható. A bagaméri élőhelyen 2019 kora tavaszán, egy hónapon át heti rendszerességgel intenzív állományfelmérés zajlott, ami négy különböző alkalommal elvégzett, teljes állományfelmérésből állt. Az adatok alapján szintén 30 méter átmérőjünek (kb. 0,07 ha) becsülték a földikutyák átlagos territóriumméretét. Ugyanakkor az adatok azt is megmutatták, hogy a populáció peremein élő egyedek territóriuma esetenként jóval nagyobb lehet, mint az állomány közepén élő példányoké. A szerbiai Deliblát homokvidékén végzett vizsgálatok szintén azt találták, hogy az egyedek aktivitásának területe (az egyedek territóriuma) rendszerint egy megközelítőleg 30 méteres (átlagosan: 24,5 m-es) körön belül található (Mikes et al. 1982).

Kötöttebb talajú élőhelyeken a földikutyák territóriumának mérete jóval kisebb. A mezőtúri élőhelyeken 2019 tavaszán végzett alapos állományfelmérések, valamint a józsai élőhelyen kiásott járatrendszer alapján ezeken az élőhelyeken a teljes járatrendszer rendszerint 20 méternél kisebb átmérőjű körön belül található. Olyan szélsőségesen táplálékbő területeken, mint a debreceni lucernás, az egyedek territóriumának átméróje esetenként nem haladja meg a nyolc métert sem.

\section{Az állományfelmérés időpontjának megválasztása}

A bagaméri populáció létrehozását követően, az áttelepített egyedek nyomon követésének eredményei világosan kijelöltek bizonyos időszakokat az év során, amikor a földikutyák rövid idő alatt sok túrást készítettek, míg a köztes időszakokban alacsony volt az egyedek járatépítő aktivitása. Ezek az időszakok jól azonosíthatóak voltak a földikutyák életének olyan jelentős eseményeivel, mint például a párzás, az utódgondozás időszaka vagy a fiatalok szétterjedése (Moldován 2014). Ezek alapján kijelölhetők azok az időszakok, amikor érdemes állományfelmérést végezni, mert az egyedek felszínről észlelhető aktivitása nagy.

A különböző nemzeti park igazgatóságok területén jelenleg folytatott földikutya-monitorozás során jellemzően vagy tavasszal vagy ősszel végzik el az állományfelméréseket. A bagaméri földikutyák éves aktivitási ciklusára vonatkozó eredmények szerint mindkét időszak megfelelő lehet. A tavasz során több aktivitási csúcsidőszak (párzás, utódgondozás) is megfigyelhető. Ugyanakkor a párzás idején a hímek mutatnak sokkal nagyobb aktivitást, az utódgondozás idején pedig a nőstények (Moldován 2014). Így a minél pontosabb állománybecslés érdekében a tavaszi időszakban több állományfelmérésre is szükség lehet. Az ősz során a földikutyáknak megfelelő mennyiségü táplálékot kell összegyüjteni és elraktározni a tél átvészeléséhez, így egy, az őszi szezon végén (novemberben) elvégzett állományfelmérés esetén az összes egyed tevékenységének a nyoma egyszerre megfigyelhető a területen. (Elméletileg az összes egyed megszámolására a tavasz végén is lehetőség nyílik, azonban az ekkorra helyenként nagyon sürüvé 
váló vegetáció miatt a túrások megtalálása problémás lehet.) Az ősz végén folytatott egyszeri állományfelmérés esetén ugyanakkor csak akkor tudunk minden egyedet azonosítani, ha nem csupán a friss túrások felmérésére kerül sor (ahogy az elterjedt módszertan szerint szokás), hanem valamennyi, így a már régebbi, ellaposodott túrások is rögzítésre kerülnek. Ez azonban további nehézségeket okozhat, hiszen jelenleg nincsenek arra vonatkozó megbízható adatok, hogy miként változik egy túrás morfológiája az idő elörehaladtával. Így nem lehet objektíven megállapítani egy túrásról, hogy az néhány hete vagy még a tavasz során keletkezett. A bagaméri eredmények alapján azt viszont biztosan tudhatjuk, hogy még a csúcsaktivitások idején sem aktív egyszerre az élőhelyen élő összes földikutya. Amikor a legtöbb egyed egyidőben készített túrásokat, akkor is az élőhelyen élö földikutyák csupán 75\%-a volt tevékeny (Moldován 2014). Tehát, ha csak a friss túrásokat számoljuk, akkor biztosan alulbecsüljük az állomány egyedszámát.

\section{A rendelkezésre álló monitorozási eredmények megbizhatósága}

A földikutya-állományfelméréseket jellemzően a természetvédelmi őrök végzik, akiknek számos más természetvédelmi feladatot is el kell látniuk a munkájuk során. Nincs lehetőségük mélyen beleásni magukat a földikutyákkal kapcsolatos szakirodalomba, sem pedig minden idejüket a földikutyák élőhelyein tölteni, hogy az állatok viselkedését, éves aktivitását megfigyelhessék. A rendelkezésre álló monitorozási adatok megbízhatósága így változatos képet mutat. Ráadásul a korábbi felmérések archív adatai kapcsán is merülhetnek fel problémák, hiszen azok különböző módszerek alkalmazásával kerültek felvételezésre, ezért csak nagyon korlátozott mértékben összehasonlíthatók. A módszertani változások miatt az adatgyüjtés megbízhatósága is változott az évek során. Kizárólag a területen található nagy túrások, párzó-, utódnevelő vagy telelőkamrák megszámolása például a jelenleg rendelkezésre álló terepi tapasztalatok alapján nem tủnik alkalmasnak az egyedszám meghatározására, az egyedszám komoly alulbecsléséhez vezet. A túrások hibás azonosítása, például, ha kizárólag a rajtuk lévő földhurkák vastagsága alapján definiáljuk a földikutyatúrásokat, szintén az egyedszámbecslés pontatlanságát eredményezheti. A sávos állományfelmérés alkalmazása, különösen, ha nem a területen található összes túrás, hanem csak a földikutyatúrások egymástól vizuálisan elkülönülő csoportjainak középpontja (vagyis a feltételezett egyedek pozíciójának) rögzítése történik, könnyen vezethet az egyedszám túlbecsléséhez. Ilyenkor ugyanis előfordulhat, hogy az egymás mellett haladó felmérők mindketten felveszik magukhoz a két zóna határán fekvő territóriummal rendelkező egyedet. A területen található valamennyi túrás felmérése és rögzítése megoldás lehet erre, hiszen így lehetőség nyílik a hibák utólagos korrigálására. 
A földikutya-áttelepítések tapasztalatai alapján az utóbbi tíz évben született monitorozási adatok pontossága között is jelentős eltérések találhatók. Az állományok egyedszámának túl- és alulbecslésére egyaránt voltak példák. Egyes esetekben valóban annyi földikutyát sikerült befogni, mint amit a felmérések előre jeleztek és az egyedek is a várt helyen voltak megtalálhatók. Máskor viszont a befogások során óriási meglepetések érték az áttelepítésben dolgozókat. Ez utóbbi visszavezethető az élőhelyek eltartóképessége terén megfigyelhető óriási különbségekre, de a nagyon kicsi és erősen fragmentált földikutya-élőhelyek monitorozása is rengeteg problémát okozhat. Ezeken a helyeken nehéz pontosan meghatározni a járatrendszerek méretét és alakját, ami az egyedszámbecslés pontatlanságát okozza. Egy fragmentált élőhelyen előforduló populáció esetében a különböző élőhelyfoltok adatai között egy állományon belül előfordult az egyedszám alul- és túlbecslése is. De nem csupán a különböző élőhelyek adatainak megbízhatósága között találhatunk különbségeket, a tapasztalatok szerint egy populáció közepén sokkal pontosabbak a felmérések adatai, a populáció szélein viszont sokkal nehezebb jól meghatározni az egyedek számát, valamint a territóriumok méretét és alakját.

Ha egy populáció egymást követő felmérési adatainak térképeit összehasonlítjuk, érdekes megfigyelést tehetünk: az egyedeket az egymást követő években gyakorlatilag ugyanott találjuk. A tapasztalatok szerint a földikutyák tartósan örzik a területüket, a territóriumok állandók és hosszabb idő alatt sem változnak. Ezt a terepi ellenőrzések is igazolták. Így, ha a felmérési adatok azt mutatják, hogy a populációban évről-évre teljesen átrendeződnek a territóriumok és az egyedszám, valamint az egyedek térbeli helyzete jelentős fluktuációt mutat, joggal gyanakodhatunk terepi adatfelvétel hibáira.

\section{Javaslatok földikutya-állományok monitorozásához}

A földikutya-áttelepítések során gyüjtött tapasztalatok és a különböző nemzeti park igazgatóságok munkatársainak tudásmegosztása révén nyert ismeretek birtokában a következő javaslatokat tesszük a földikutya-állományok megbízható, monitorozási célú felmérése érdekében:

(i) Az állományfelmérések során elengedhetetlennek tartjuk a járatrendszerek megnyitását. Kizárólag a túrások vizsgálata alapján ugyanis sok esetben nem lehetséges a földikutya egyértelmủ azonosítása. A túrást készítő faj hibás meghatározása viszont a felmérés eredményének súlyos pontatlanságát okozza. A járatok megbontása kapcsán felvetődhet, hogy ez esetleg olyan beavatkozás az állatok életébe, melynek természetvédelmi relevanciája lehet. Ám a járatrendszer megnyitása éppen csak a járat megtalálását jelenti a túrás közelében. Ez már lehetővé teszi a járat méretének és jellemzőinek megfigyelését, nincs szükség a járatok 
hosszabb vagy mélyebb feltárására. A Hortobágyi Nemzeti Park Igazgatóság földikutya-állományai esetén, ahol a járatrendszerek megnyitása 2018 óta részét képezi a monitorozási protokollnak, ezidáig semmilyen, az állományokra gyakorolt káros hatást nem lehetett megfigyelni.

(ii) A minél objektívebb eredmény érdekében a monitorozás során javasoljuk valamennyi, a területen található, friss túrás rögzítését, nem csak a túráscsoportok középpontjának koordinátáit (vagyis az egyedek feltételezett pozícióját). Az egyedek feltételezett pozíciójának és az összes friss túrásnak az együttes felvételezése a tapasztalatok szerint rendkívül hasznos az adatok térinformatikai feldolgozása során. Az állományfelmérések eredményei ezáltal sokkal inkább összehasonlíthatók lesznek egymással, és számos további elemzésre is lehetőség nyílik a későbbiekben.

(iii) A monitorozás időpontjául a tavaszi időszakot javasoljuk, és egy aktivitási időszakon belül legalább két alkalommal szükséges elvégezni a felméréseket, minimum egyhetes különbséggel. A tavaszi időszakban több olyan, a földikutyák szempontjából fontos esemény történik, amelyekben joggal várható a populációt alkotó egyedek döntő többségének aktivitása. Ha lehetséges, célszerü lenne mind a párzási időszakban (a télvégi friss túrások megjelenésekor, nagyjából februártól március elejéig), mind az utódgondozási időszakban (bő egy hónappal az előbbi eseményt követően) két-két felmérést végezni. Bár mindez jelentős terepi munkát jelent, de így jelentősen növelhető az egyedszámbecslés pontossága (Horváth 1999). A felmérések számának további növelése ugyan minden bizonnyal tovább növelhetné az egyedszámbecslés pontosságát, ám négynél több felmérésnek a nemzeti parkok munkatársai számára rendszerint zsúfolt tavaszi időszak során nincs realitása, ezért nem javasoljuk.

(iv) Amennyiben mégis az őszi monitorozás mellett döntünk, szintén szükséges minimum két alkalommal elvégezni a felméréseket, legalább egyhetes különbséggel a felmérések között. Máskülönben fontos, hogy ne csupán a friss, de a még észlelhető régi túrások koordinátáit is rögzítsük (Horváth 1999). Ha ugyanis csupán egyszeri felmérést végzünk, és kizárólag a friss túrások adatait vesszük fel, akkor biztosan alulbecsüljük az állományt, hiszen a korábbi megfigyelések szerint sohasem aktív egy időben az összes, a területen élő állat. A régi túrások korának megállapítása azonban nagyon nehéz, és jelenleg nem ismert hozzá megbízható kutatási adat. A régi túrások morfológiai jellemzőit az időjárási események mellett nagymértékben befolyásolják az élőhely talajtani tulajdonságai is.

(v) A felmérések során javasolt a már rögzített pozíciójú túrásokat eltaposni vagy elsimítani, így a későbbi felmérések során pontosan ismert lesz a megtalált túrások maximális kora, illetve a rátúrások is könnyen észlelhetők lesznek. Mivel a felmérésekhez használt GPS készülékek pontossága általában nem teszi lehetö- 
vé a korábban már felmért túrások egyértelmủ azonosítását, ezért ez a lépés nagy jelentőségü lehet.

(vi) A minél hatékonyabb földikutya-monitorozási módszerek kifejlesztése érdekében nagyon fontos, hogy az ország különböző földikutya-élőhelyein dolgozó, felmérést végző szakemberek rendszeresen konzultáljanak egymással. Az egyéni tapasztalatok megosztása és a felmerülő problémák megvitatása a továbblépés kulcsa. A Hortobágyi, Körös-Maros, és Duna-Ipoly Nemzeti Park Igazgatóságok munkatársainak részvételével zajló eddigi események tapasztalatai nagymértékben hozzájárultak egy olyan, egységes szemlélet kialakulásához, ami nélkülözhetetlen egy általánosan használható protokoll kidolgozásához. Ugyanakkor felhívták a figyelmet arra is, hogy az egyes élőhelyeknek olyan különleges jellemzői lehetnek, amik a felmérés módszertanát befolyásolják, és ezeket figyelembe kell venni egy egységes protokoll kidolgozásakor. A szerzők tapasztalatai szerint ugyanis egy a Kárpát-medencében bárhol alkalmazható, egységes földikutya-monitorozási protokoll megalkotásának éppen az a legnagyobb nehézsége, hogy olyan módszertan kidolgozására van szükség, mely a változatos (talajtani) adottságú földikutya-élöhelyek mindegyikén jól alkalmazható.

Köszönetnyilvánitás - Köszönetet szeretnénk mondani a Körös-Maros Nemzeti Park Igazgatóság munkatársainak, külön is kiemelve Roth Melindát és Boldog Gusztávot, valamint a Kiskunsági Nemzeti Park Igazgatóság munkatársainak, különösen Vajda Zoltánnak, illetve a Duna-Ipoly Nemzeti Park Igazgatóság munkatársainak, különösképp Csóka Annamáriának és Vidra Tamásnak, amiért tapasztalataikat megosztották velünk, és az itt bemutatott vizsgálatokat és terepi felméréseket nagymértékben segítették. További köszönettel tartozunk Csorba Gábornak (Magyar Természettudományi Múzeum) és Váczi Olivérnek (Herman Ottó Intézet Nonprofit Kft.), akik pótolhatatlan segítséget nyújtottak, és akikre mindig számíthattunk. Szeretnénk köszönetet mondani Estók Péternek és Katona Krisztiánnak a kézirat fejlesztése érdekében tett hasznos javaslataikért.

\section{Irodalomjegyzék}

Bihari, Z., Balogh, P., Pető, N. (2009): A nyugati földikutya (Spalax leucodon Nordmann, 1840) hazai állománynagysága és a faj térhasználata a legeltetés függvényében a Hajdúbagosi élőhely példáján bemutatva. Természetvédelmi Közlemények 15: 46-56.

Boldog, G. (2010): Talajlakó emlősök túrásmorfológiai vizsgálata, különös tekintettel a nyugati földikutya (Spalax leucodon) természetvédelmi monitorozására. Crisicum 6: 199-211.

Boldog G. (2011): A nyugati földikutya (Nannospalax (superspecies leucodon)) állománybecslésének módszerei túrásdenzitás elemzés alapján. MSc szakdolgozat. Debreceni Egyetem, Debrecen, $39 \mathrm{p}$.

Delić, J. (2007): A földikutya (Spalax leucodon) populációjának állapotkövetése a szabadkai Homokvidék Tájvédelmi Területen. Ludasi jegyzetek 6: 37-40. 
Horváth, Gy. (1999): A nyugati földikutya (Nannospalax leucodon) elterjedésének és állománynagyságának regionális szintủ monitorozása. In: A Nemzeti Biodiverzitás-monitorozó Rendszer. Védett és veszélyeztetett fajok megfigyelése. KVM jelentés. Környezetvédelmi Minisztérium, Budapest, $7 \mathrm{p}$.

Horváth, R., Vadnay R. (2001): A Hortobágyi Nemzeti Park Igazgatóság földikutya (Spalax leucodon) állományának vizsgálata. Kutatási jelentés. Karszt Egyesület, Szögliget, 21 p.

Horváth, R., Vadnai, R. (2006): A földikutya. Szabolcs-Szatmár-Beregi Természet- és Környezetvédelmi Kulturális Értékőrző Alapítvány, Fehérgyarmat, 20 p.

Li, K., Hong, W., Jiao, H., Wang, G. D., Rodriguez, K. A., Buffenstein, R., Zhao, Y., Nevo, E., Zhao, H. (2015): Sympatric speciation revealed by genome-wide divergence in the blind mole rat Spalax. Proceedings of the National Academy of Sciences 112(38): 11905-11910. https://doi. org/10.1073/pnas.1514896112

Lövy, M., Šklíba, J., Hrouzková, E., Dvořáková, V., Nevo, E., Šumbera, R. (2015): Habitat and burrow system characteristics of the blind mole rat Spalax galili in an area of supposed sympatric speciation. PLoS One 10(7): e0133157. https://doi.org/10.1371/journal.pone.0133157

Mikes, M., Habijan, V., Savić, I. (1982): Distribution and dispersion of the species Spalax leucodon Nordmann, 1840. Säugetierkundliche Mitteilungen 30: 161-167.

Mills, L. S., Citta, J. J., Lair, K. P., Schwartz, M. K., Tallmon, D. A. (2000): Estimating animal abundance using noninvasive DNA sampling: promise and pitfalls. Ecological Applications 10(1): 283-294. https://doi.org/10.1890/1051-0761(2000)010[0283:EAAUND]2.0.CO;2

Moldován, O. (2014): Az erdélyi földikutya Nannospalax (leucodon) transsylvanicus új populációjának létrehozása és az elsô év tapasztalatai. MSc szakdolgozat. Debreceni Egyetem, Debrecen.

Németh, A. (2011): A kárpát-medencei földikutyák (Rodentia: Spalacinae) rendszertana, elterjedése és természetvédelmi helyzete. Doktori értekezés. Eötvös Loránd Tudományegyetem, Budapest, $136 \mathrm{p}$.

Németh, A., Krnács, Gy., Tamás, Á., Vajda, Z. (2015): A délvidéki földikutya (Nannospalax montanosyrmiensis) magyarországi állományainak alapállapot felmérése. Kutatási jelentés, RAPTORSPREYLIFE Projekt. Kiskunsági Nemzeti Park Igazgatóság, Kecskemét, 15 p.

Németh, A., Moldován, O., Szél, L. (2020): Mindig útban? - Városias környezetben fennmaradt földikutya-állományok megőrzésének kihívásai Magyarországon. Természetvédelmi Közlemények 26: 52-69. https://doi.org/10.20332/tvk-jnatconserv.2020.26.52

Palotás, G. (1982): Jelentés a Hajdúbagosi földikutya rezervátumról. Szakértői vélemény (kézirat). Debreceni Agrártudományi Egyetem, Debrecen, 3 p.

Palotás, G. (1987): A földikutya - Spalax (Microspalax) leucodon NORDMANN 1840. Kézirat, Debreceni Agrártudományi Egyetem, Debrecen. 11 p.

Páll, D. G., Sipos, Gy. (2017): Az Öttömösre telepitett délvidéki földikutya-állomány területhasználatának / járatkészitési szokásainak nyomon követése roncsolásmentes vizsgálatokkal. Kutatási jelentés. OSL Hungary Kft., Szeged, 34 p.

Ruzsa, J., Schneider, V., Farkas, J., Németh, A. (2020): A magyarországi földikutya-áttelepítések értékelése. Természetvédelmi Közlemények 26: 70-92. https://doi.org/10.20332/tvk-jnatconserv.2020.26.70

Schemske, D. W., Husband, B. C., Ruckelshaus, M. H., Goodwillie, C., Parker, I. M., Bishop, J. G. (1994): Evaluating approaches to the conservation of rare and endangered plants. Ecology 75(3): 584-606. https://doi.org/10.2307/1941718

Schneider, V., Ruzsa, J., Czabán, D. G., Németh, A. (2019): Egy földikutya-áttelepítés tanulságai. Természetvédelmi Közlemények 25: 14-33. https://doi.org/10.20332/tvk-jnatconserv.2019.25.14 
Šklíba, J., Lövy, M., Koeppen, S. C., Pleštilová, L., Vitámvás, M., Nevo, E., Šumbera, R. (2016): Activity of free-living subterranean blind mole rats Spalax galili (Rodentia: Spalacidae) in an area of supposed sympatric speciation. Biological Journal of the Linnean Society 118(2): 280291. https://doi.org/10.1111/bij.12741

Yoccoz, N. G., Nichols, J. D., Boulinier, T. (2001): Monitoring of biological diversity in space and time. Trends in Ecology \& Evolution 16(8): 446-453. https://doi.org/10.1016/S01695347(01)02205-4

Vadnay R. (2000): A földikutya (Spalax leucodon NORD.) helyzete Magyarországon. Szakdolgozat. Eszterházy Károly Főiskola, Eger, 52 p.

Vásárhelyi, I. (1926): Adatok a földikutya (Spalax hungaricus hungaricus Nhrg.) életmódjának ismeretéhez. Állattani Közlemények 23(3-4):169-226.

Vásárhelyi, I. (1930): A vakondok vára és a kószapocok fészke. Állattani Közlemények 27: 173-181.

Végh, M. (1986): A Hajdúbagosi Földikutya Rezervátum öko-faunisztikai vizsgálata. Szakdolgozat. Debreceni Agrártudományi Egyetem, Debrecen, 75 p.

Vidacs, J. A., Farkas, J., Németh, A. (2013): Konvergenciák, divergenciák és adaptáció a talajlakó életmódot folytató emlősöknél. Állattani Közlemények 98: 21-46.

Zidarova, S. A., Kostova, R. D. (2021): A pilot monitoring survey of the lesser blind mole-rat Nannospalax (superspecies leucodon) (Mammalia: Rodentia) in Bulgaria. Acta Zoologica Bulgarica 73(1):107-112. http://www.acta-zoologica-bulgarica.eu/002413

Zuri, I., Terkel, J. (1996): Locomotor patterns, territory and tunnel utilization in the mole-rat Spalax ehrenbergi. Journal of Zoology London 240: 123-140. https://doi.org/10.1111/j.1469-7998.1996. tb05490.x

Zuri, I., Terkel, J. (1997): Summer tunneling activity of mole rats (Spalax ehrenbergi) in a sloping field with moisture gradient. Mammalia 61: 47-54. https://doi.org/10.1515/mamm.1997.61.1.47 


\title{
Recommendations for a unified monitoring system of Blind mole rat populations in Hungary
}

\author{
Orsolya Moldován ${ }^{1,2}$, Viktor Schneider ${ }^{3}$, László Szél ${ }^{1} \&$ \\ Attila Németh ${ }^{2,4^{*}}$ \\ ${ }^{1}$ Hortobágy National Park Directorate, H-4024 Debrecen, Sumen u. 2, Hungary \\ ${ }^{2}$ University of Debrecen, Department of Nature Conservation, Zoology and Game \\ Management, H-4032 Debrecen, Böszörményi út 138, Hungary \\ ${ }^{3}$ Kiskunság National Park Directorate, H-6000 Kecskemét, Liszt Ferenc u. 19, Hungary \\ ${ }^{4}$ BirdLife Hungary - Hungarian Ornithological and Nature Conservation Society, \\ H-1121 Budapest, Költö u. 21, Hungary \\ *E-mail: dr.attila.nemeth@gmail.com \\ Blind mole rats are among the most endangered mammals in Hungary. Due to their exclusively sub- \\ terranean lifestyle, determining the number of individuals in a habitat, and monitoring the changes \\ of the number of individuals in a population are very difficult. However, it is essential to get reli- \\ able data about their population numbers. Since the 1980's, a number of initiatives have been taken \\ to develop methodologies for monitoring these rodents. In our paper, we review the methods used \\ in Hungarian nature conservation practice. Based on the practical experience gained on the field \\ in recent years, we discuss the difficulties of monitoring, such as the identification of blind mole \\ rat mounds, problems caused by the pedological diversity of different habitats, or difficulties in \\ choosing the right time of monitoring. Recommendations are formulated for the development of a \\ unified monitoring protocol that can be used in any blind mole rat habitat in the Carpathian Basin.
}

Keywords: Nannospalax (superspecies leucodon), population survey, estimation methods for the number of individuals, monitoring, methodology, habitat characteristics 